\title{
Effect of sugar and water contents on non-expanded cassava flour extrudates
}

\author{
Efeitos dos teores de açúcar e água em produtos extrusados não expandidos de farinha de mandioca
}

\author{
Juan Antonio Ruano ORTIZ1 ${ }^{1}$ Carlos Wanderlei Piler de CARVALHO², Diego Palmiro Ramirez ASCHERI ${ }^{3 *}$, \\ José Luis Ramirez ASCHERI ${ }^{2}$, Cristina Tristão de ANDRADE ${ }^{4}$
}

\begin{abstract}
The effects of sucrose and water contents on cassava flour processed by extrusion at varied concentrations of sucrose (0-20\% w/w) and water $(28-42 \% \mathrm{w} / \mathrm{w})$ were studied by applying response surface methodology. The extrusion of the mixtures was performed in a twin screw extruder fitted to a torque rheometer. The specific mechanical energy (SME) dissipated inside a conical twin-screw extruder was measured. Water absorption index (WAI), water solubility index (WSI) and paste viscosity readings (cold viscosity (CV), peak viscosity (PV), breakdown (BD) and set back (SB)) during a gelatinization-retrogradation cycle measured in a Rapid Visco Analyzer were determined on non-directly extruded products. The results indicated that SME and WSI decreased as a function of water and sucrose contents. WAI and pasting properties were influenced by water content. A non antiplasticizing effect of the sucrose content was observed on pasting properties, suggesting that sucrose did not reduce the availability of water available for gelatinizing cassava flour during the extrusion process. The nature of the optimum point was characterized as a saddle point for WAI, WSI, PV and BD, whereas SME showed a maximum and CV and SB a minimum. The results indicated to be valuable for the production of non-expanded cassava flour extrudates with desirable functional properties for specific end users.

Keywords: RVA paste viscosity; specific mechanical energy; water absorption index; water solubility index; response surface methodology; physicochemical properties.
\end{abstract}

\section{Resumo}

Foram estudados os efeitos da sacarose e da água de mistura no processamento de farinha de mandioca por extrusão. As variações de sacarose $(0-20 \% \mathrm{p} / \mathrm{p})$ e água $(28-42 \% \mathrm{p} / \mathrm{p})$ foram estudadas empregando-se metodologia de superfície de resposta. O processo de extrusão foi conduzido em uma extrusora de dupla rosca acoplado a um reômetro de torque. A energia mecânica específica (SME) dissipada no final da extrusora foi calculada. As amostras extrusadas foram analisadas quanto aos índices de absorção de água (WAI) e de solubilidade em água (WSI), e quanto às propriedades de pasta durante o ciclo de gelatinização/retrogradação usando-se um analisador rápido de viscosidade (viscosidade a frio (CV), pico de viscosidade (PV), breakdown e setback). SME e WSI diminuíram em função dos teores de água e açúcar. WAI e as propriedades de pasta foram influenciadas pelo teor de água. Não foi observado o efeito antiplastificante da sacarose nas propriedades de pasta, indicando que a adição de açúcar na mistura de farinha de mandioca não reduziu a capacidade da água em gelatinizar o amido durante o processo de extrusão. A natureza do ponto ótimo para o WAI, PV e BD foi uma sela, enquanto que para SME foi máximo e para CV e SB foi mínimo. Estes resultados podem ser usados na fabricação de produtos extrusados não expandidos de farinha de mandioca contendo açúcar com desejáveis propriedades funcionais para fins específicos.

Palavras-chave: viscosidade de pasta; energia mecânica específica; índice de absorção de água; índice de solubilidade em água; propriedades físico-químicas.

\section{Introduction}

Cassava is a root found in tropical regions that to be stored it usually has to be processed into starch and flour forms since it perishes quickly. For cassava flour, some fibers and proteins are kept in the final product, thereby contributing to its chemical composition, darker color and flavor, when compared to the starch form.

Extrusion technology has been widely used to produce a large variety of starch-based products, such as infant food formulations, ready-to-eat breakfast cereals, instant soups and puffed snacks. This process combines heat, shearing and pressure, resulting in the gelatinization of granular starch, denaturation of protein and the formation of complexes among starch, lipids and proteins (CAMIRE, M. E.; CAMIRE, A.; KRUMHAR, 1990).

Ingredients, such as emulsifiers, fats and oils, sugars, salts, protein, fibers, vitamins and minerals are frequently added into starch formulations in order to change the final product's physical, sensory, and nutritional properties. The effect of sugars,

\footnotetext{
Recebido para publicação em 28/3/2008

Aceito para publicação em 4/1/2009 (003379)

Departamento de Tecnologia de Alimentos, Programa Ciência e Tecnologia de Alimentos, Universidade Federal Rural do Rio de Janeiro - UFRRJ, Km 47, Seropédica - RJ, Brazil

2 Embrapa Agroindústria de Alimentos, Av. das Américas, 29501, Guaratiba, CEP 23020-470, Rio de Janeiro - RJ, Brazil

${ }^{3}$ Unidade Universitária de Ciências Exatas e Tecnológicas, Universidade Estadual de Goiás - UEG, Rodovia BR 153, Km 98, CEP 75001-970, Anápolis - GO, Brazil,

E-mail: ascheridpr@gmail.com

${ }^{4}$ Instituto de Macromoléculas Professora Eloisa Mano, Universidade Federal do Rio de Janeiro - UFRJ, CP 68525, CEP 21945-970, Rio de Janeiro - RJ, Brazil

${ }^{*}$ A quem a correspondência deve ser enviada
} 
particularly sucrose, on the functional properties of extruded cereal flours has been investigated by a number of researchers who have used different techniques to evaluate degrees of gelatinization, retrogradation, expansion, water solubility, thermal and other properties of extrudates (BARRETT et al., 1995; CARVALHO; MITCHELL, 2000, 2001; FARHAT et al., 2000; FARHAT; MOUSIA; MITCHELL, 2003; HSIEH et al., 1993; SOPADE; LE GRYS, 1991). Sucrose has been found to affect significantly the structure and texture of extrudates and the magnitude of sucrose effect may vary according to the cereal source. Carvalho and Mitchell (2000) found that the sectional expansion of wheat flour extrudates was less affected by sucrose than by corn grit extrudates, which was attributed to the starch molecular integrity of wheat being lower than corn starch under severe shear condition. Structural changes have also been attributed to competition for water (HSIEH; PENG; HUFF, 1990) and inhibition of starch gelatinization (JANG et al., 2001). The modification of the extrudate texture as a consequence of increasing the sucrose concentration has been attributed to the plasticization of starch-based products by decreasing the glass transition temperature, increasing product density, and reducing sectional expansion (FAN; MITCHELL; BLANSHARD, 1996).

The present work investigated the interactive effect of sucrose and moisture on the extrusion of cassava flour, in particular specific mechanical energy, water absorption index, water solubility index and the pasting properties of non-directly extrudate products.

\section{Materials and methods}

\subsection{Materials}

Cassava flour, donated by Granfino Alimentos (Rio de Janeiro, Brazil), was used as starch source. The chemical composition of the cassava flour was $77.1 \%$ carbohydrates, $1.13 \%$ proteins, $0.27 \%$ fat, $0.76 \%$ ash, and $11.64 \%$ moisture. Commercial sucrose was acquired from local markets (Rio de Janeiro, Brazil).

\subsection{Preparation of extruded products}

Cassava flour and sucrose/water mixtures at different contents (Table 1) were mixed in a $10 \mathrm{~kg}$ capacity planetary mixer Siam-Util (São Paulo, Brazil) and then kept at $18{ }^{\circ} \mathrm{C}$ for 24 hours before extrusion processing.

The extrusion of the mixtures was performed in a Haake Rheocord 9000 System torque rheometer (Karlsruhe, Germany) fitted with a conical twin screw at a speed of $150 \mathrm{rpm}$. The

Table 1. Coded levels for the central composite design.

\begin{tabular}{cccccc}
\hline \multirow{2}{*}{$\begin{array}{c}\text { Independent } \\
\text { variables }\end{array}$} & \multicolumn{6}{c}{ Levels } \\
\cline { 2 - 6 } & $-\alpha^{\mathrm{a}}$ & -1 & 0 & 1 & $\alpha$ \\
\hline Water content (\%), $\mathrm{x}_{1}{ }^{\mathrm{b}}$ & 27.9 & 30.0 & 35.0 & 40.0 & 42.1 \\
Sucrose content (\%), $\mathrm{x}_{2}{ }^{\mathrm{c}}$ & 0.1 & 3 & 10.0 & 17.0 & 19.9 \\
\hline
\end{tabular}

${ }^{\mathrm{a}} \alpha=1.414$; ${ }^{\mathrm{b}}$ Moisture content (\% w.b.); and ' $\mathrm{c}$ sucrose content was based on dry cassava flour fraction (\%). extrusion temperature profile was maintained constant at 70 , $100,90,90,70^{\circ} \mathrm{C}$ from feed zone to die end. The feeding rate was $4.5 \mathrm{~kg} \cdot \mathrm{h}^{-1}$. After processing, the extrudates were immediately placed in plastic bags and stored in freezing conditions.

\subsection{Response variables}

The response of the experiment was total specific mechanical energy (SME), water absorption index (WAI), water solubility index (WSI) and properties of cold pasting viscosity (CV), peak viscosity (PV), breakdown (BD), and setback (SB).

\section{Specific mechanical energies (SME)}

Specific mechanical energies (SME) were calculated according to the equation below (CARVALHO; MITCHELL, 2000) Equation (1).

$\mathrm{SME}=\frac{2 \pi \cdot \mathrm{n} \cdot \mathrm{ST}}{60 \mathrm{G}}$

where $\mathrm{n}$ refers to the screw speed (rpm), ST refers to the screw torque (N.m) and G refers to the mass flow rate $\left(\mathrm{kg} \cdot \mathrm{h}^{-1}\right)$. After steady flow was achieved, the mass flow rate was determined by measuring the output mass flow in 60 seconds and the average of three readings was considered. Screw speed and torque were measured by the torque rheometer unit and recorded by the control cabinet Brabender Modular System (Duisburg, Germany).

\subsection{Functional properties determinations}

The frozen samples stored in plastic bags were thawed at room temperature, and dried at $60^{\circ} \mathrm{C}$ for 8 hours in a fan oven. After drying, the samples were milled in a disk mill (Perten Instruments 3600, Huddinge, Switzerland) and in a roller mill (Brabender QU-J, Duisburg, Germany) fitted with a $200 \mu \mathrm{m}$ sieve which defined the particle size used for further analyses.

\section{Water absorption index (WAI) and} water solubility index (WSI)

The water absorption index (WAI) measures the volume occupied by the starch granule after swelling in excess of water, while water solubility index (WSI) determines the amount of free molecules leached out from the starch granule in addition to excess water. WAI and WSI determination followed the methodology described by Anderson et al. (1969) with modifications. One gram of sample (dry basis) was mixed with $10 \mathrm{~mL}$ distilled water in a centrifuge tube which was vigorously agitated in a standard laboratory vortex shaker until complete dispersion and then placed in a shaker for 30 minutes. The suspension was centrifuged on a centrifuge Hermle Z 383 (Wehingen, Germany) at $3000 \mathrm{rpm}(5654 \times \mathrm{g})$. WAI was expressed as the weight of precipitated per gram of sample. The supernatant was evaporated in a fan oven (Fabbe 170, São Paulo, Brazil) at $105^{\circ} \mathrm{C}$ until constant weight and the WSI was the weight of dry solids in the supernatant represented as a percentage of the sample's original weight. 


\section{Pasting properties}

A Rapid Visco Analyser (RVA, Newport Scientific Pty. Ltd., Warriewood, Australia) was used to measure the apparent viscosity of samples as a function of temperature (CARVALHO; MITCHELL, 2001). Three grams of sample, adjusted to $14 \%$ water on a wet basis, were added to $25 \mathrm{~g}$ of distilled water. The samples were initially kept at $25^{\circ} \mathrm{C}$ for 4 minutes, then heated to $95^{\circ} \mathrm{C}$ at a constant heating rate of $14^{\circ} \mathrm{C} /$ minute, held at this temperature for 3 minutes, cooled down to $25^{\circ} \mathrm{C}$ in 5 minutes at the same rate, and finally held at $25{ }^{\circ} \mathrm{C}$ for an additional 4 minutes. The paste viscosity responses were: cold viscosity ( $\mathrm{CV}$, defined as the peak viscosity in the beginning of the RVA curve at $25^{\circ} \mathrm{C}$ ), peak viscosity (PV, maximum viscosity during heating), breakdown (BD, difference between the peak viscosity and the lowest viscosity after heating ramp) and setback (SB, difference between the maximum viscosity during cooling and the lowest viscosity after the heating ramp).

\subsection{Experimental design and data analysis}

The experimental design chosen for this study was that of Centre Composite Design (CCD), for two variables (MONTGOMERY, 1997). Three levels, such as low, medium and high, denoted as $-1,0$ and +1 , respectively, and two axial points, such as star low and star high, denoted as $-\alpha$ and $\alpha$, in coded level of variables, were used to fit a full quadratic response surface model and later approximated to obtain the optimal response.

Table 1 shows the design variables selected in this study with actual and coded levels, along with the response variables. Four duplicates are included at the centre of the design. The total number of test runs needed for this design was 12 . The experimental conditions were selected for each variable based on prior studies. Experiments were carried out according to the design points with independent variables, namely water content $\left(\mathrm{x}_{1}\right)$, and sucrose content $\left(\mathrm{x}_{2}\right)$.

The Response Surface Methodology (RSM) was applied to analyze the effect of independent variables on response parameters (SME, WAI, WSI, CV, PV, BD and SB) by matching the responses studied $(Y)$ with the code factors $\left(\mathrm{x}_{\mathrm{i}}, \mathrm{i}=1,2,3, \ldots, \mathrm{n}\right)$ using the polynomial model associated with the experimental design (KHURI; CORNELL, 1987) Equation (2).

$\mathrm{Y}=\mathrm{b}_{0}+\sum_{\mathrm{i}=1}^{\mathrm{k}} \mathrm{b}_{\mathrm{i}} \mathrm{x}_{\mathrm{i}}+\sum_{\mathrm{i}=1}^{\mathrm{k}} \mathrm{b}_{\mathrm{ii}} \mathrm{x}_{\mathrm{i}}^{2}+\sum_{\mathrm{i}<\mathrm{j}} \mathrm{b}_{\mathrm{ij}} \mathrm{x}_{\mathrm{i}} \mathrm{x}_{\mathrm{j}}+\varepsilon$

Coefficients $\mathrm{b}_{0}, \mathrm{~b}_{\mathrm{i}}$ and $\mathrm{b}_{\mathrm{ii}}$ represent the constant, linear and quadratic effects, respectively, and $b_{i j}$ represents the interaction effect of code factor $\mathrm{x}_{\mathrm{i}}$. The statistical package Statistica 6.0 (StatSoft, Tulsa, USA) was used for regression and ANOVA analysis. Response surface graphs were obtained from the regression equation in actual levels of variables, keeping the response function on the $\mathrm{Z}$ axis with $\mathrm{X}$ and $\mathrm{Y}$ axes representing the independent variables, while keeping the other variable constant at the center (corresponding to 0,0 coded level) points.
The results were validated and confirmed by performing the experiments with values which were not the design points.

\subsection{Nature of optimum and simultaneous optimization}

Canonical analysis (MYERS, 1971) was performed on the predicted quadratic polynomial model to examine the overall shape of responses and to characterize the nature of the stationary point. Optimization of the response function consists of its transition from its origin to the stationary points. The response function was expressed in terms of the new variables, the axis which corresponds to the principal axis of the contour system. The roots of the auxiliary equation were calculated initially to know the nature of the optimum point. The response would be maximum, if all the roots showed negative values and minimum if all the roots showed positive values and if they showed a combination of positive and negative values, thus representing a saddle point or minimax.

Simultaneous optimization was carried out according to the methodology suggested by Derringer and Suich (1980), where all the individual desirability functions were combined into an overall desirability function, which is defined as the geometric mean of individual desirability functions. The higher the desirability value, the more desirable is the system.

\section{Results and discussion}

The effects of the independent variables on the response function of the targeted parameters are shown in Table 2 (in coded levels of variables).

All main, linear, quadratic, and interaction effects were calculated for each model. Table 3 shows the regression coefficients as well as the correlation coefficients obtained for each model. The correlation coefficients for the responses $\left(\mathrm{R}^{2}\right)$ were considerably high for response surfaces and indicated that fitted quadratic models accounted for more than $83 \%$ of the variance of the experimental data $(p<0.05)$. Based on $\mathrm{t}$-statistics, the only regression coefficients significant at 95 and 99\% levels were selected for developing the models as follows:

Specific mechanical energy $\left(\mathrm{Y}_{1}\right)=96.25-22.08 \mathrm{X}_{1}-8.24 \mathrm{X}_{2}-$ $12.89 \mathrm{X}_{1}^{2}$

Water absorption index $\left(\mathrm{Y}_{2}\right)=12.28-5.27 \mathrm{X}_{1}$

Water solubility index $\left(\mathrm{Y}_{3}\right)=7.17+0.57 \mathrm{X}_{1}-0.62 \mathrm{X}_{2}-0.51 \mathrm{X}_{1}^{2}$

Cold viscosity $\left(\mathrm{Y}_{4}\right)=4138.37-53.94 \mathrm{X}_{1}^{2}$

Peak viscosity $\left(\mathrm{Y}_{5}\right)=3180.62+1252.65 \mathrm{X}_{1}$

Breakdown $\left(\mathrm{Y}_{6}\right)=2882.12+1167.02 \mathrm{X}_{1}$

Setback $\left(\mathrm{Y}_{7}\right)=581.00+176.78 \mathrm{X}_{1}+44.97 \mathrm{X}_{2}+186.53 \mathrm{X}_{1}^{2}$

The water content had a greater negative linear effect on specific mechanical energies and water absorption index, but a positive linear effect on water solubility index, peak viscosity, breakdown viscosity and set back viscosity and had a negative and positive quadratic effect on specific mechanical energies, water solubility index and cold viscosity and set back viscosity, respectively. The sucrose content had a negative linear effect on 
Table 2. Experimentally determined dependent non-expanded cassava flour extrudate properties.

\begin{tabular}{cccccrccc}
\hline Water content (\%) & Sucrose content (\%) & SME (W.h.kg-1) & WAI (g/g) & WSI (\%) & CV (cP) & PV (cP) & BD (cP) & SB (cP) \\
\hline 1.4 & 0.0 & 43.9 & 5.0 & 6.9 & 403.0 & 5379.5 & 4771.5 & 1310.0 \\
1.0 & 1.0 & 39.1 & 7.9 & 7.2 & 2707.0 & 4420.0 & 3954.0 & 923.5 \\
0.0 & 1.4 & 90.9 & 15.3 & 6.0 & 2976.0 & 2233.0 & 1900.0 & 734.5 \\
-1.0 & 1.0 & 92.5 & 16.0 & 5.5 & 2584.5 & 2139.0 & 1796.5 & 725.0 \\
-1.4 & 0.0 & 103.0 & 20.6 & 5.5 & 2395.0 & 1666.0 & 1338.0 & 649.0 \\
-1.0 & -1.0 & 111.5 & 17.6 & 6.6 & 2581.5 & 1806.0 & 1528.5 & 588.0 \\
0.0 & -1.4 & 101.0 & 14.7 & 8.6 & 4148.0 & 3202.0 & 2872.5 & 615.5 \\
1.0 & -1.0 & 71.8 & 5.8 & 7.5 & 701.0 & 4294.5 & 3851.5 & 869.0 \\
0.0 & 0.0 & 95.1 & 15.0 & 7.3 & 3623.5 & 2604.0 & 2327.0 & 534.0 \\
0.0 & 0.0 & 87.1 & 11.3 & 7.0 & 3550.0 & 3140.5 & 2836.5 & 573.0 \\
0.0 & 0.0 & 101.1 & 12.5 & 7.1 & 4470.0 & 3462.0 & 3161.0 & 619.0 \\
0.0 & 0.0 & 101.7 & 10.3 & 7.2 & 4910.0 & 3516.0 & 3204.0 & 598.0 \\
\hline
\end{tabular}

$\mathrm{SME}=$ specific mechanical energy WAI = water absorption index; WSI = water solubility index; $\mathrm{CV}=$ cold viscosity; $\mathrm{PV}=$ peak viscosity; $\mathrm{BD}=$ breakdown; and $\mathrm{SB}=$ set back.

Table 3. Estimated coefficients of the fitted quadratic equation for different responses based on t-statistic.

\begin{tabular}{|c|c|c|c|c|c|c|c|c|c|c|c|c|c|c|}
\hline \multirow[t]{3}{*}{ Factor } & \multicolumn{14}{|c|}{ Estimated coefficients } \\
\hline & \multicolumn{2}{|c|}{$\mathrm{Y}_{1}$} & \multicolumn{2}{|c|}{$\mathrm{Y}_{2}$} & \multicolumn{2}{|c|}{$\mathrm{Y}_{3}$} & \multicolumn{2}{|c|}{$\mathrm{Y}_{4}$} & \multicolumn{2}{|c|}{$\mathrm{Y}_{5}$} & \multicolumn{2}{|c|}{$\mathrm{Y}_{6}$} & \multicolumn{2}{|c|}{$\mathrm{Y}_{7}$} \\
\hline & Coeff. & t-Value & Coeff. & $\mathrm{t}$-Value & Coeff. & $\mathrm{t}$-Value & Coeff. & $\mathrm{t}$-Value & Coeff. & t-Value & Coeff. & $\mathrm{t}$-Value & Coeff. & $\mathrm{t}$-Value \\
\hline $\mathrm{X}_{0}$ & $96.26^{\star *}$ & 28.36 & $12.28^{\star *}$ & 12.10 & $7.17^{\star \star}$ & 93.74 & $4138.36^{* *}$ & 12.49 & $3180.63^{\star *}$ & 15.20 & $2882.13^{\star *}$ & 14.24 & $581.00^{* *}$ & 31.80 \\
\hline $\mathrm{X}_{1}$ & $-22.08^{\star *}$ & -9.20 & $-5.27^{\star \star}$ & -7.34 & $0.57^{\star *}$ & 10.49 & $-571.89^{\text {ns }}$ & -2.44 & $1252.65^{\star *}$ & 8.46 & $1167.03^{* *}$ & 8.15 & $176.79^{* *}$ & 13.68 \\
\hline $\mathrm{X}_{1}^{2}$ & $-12.89^{*}$ & -4.80 & $-0.26^{\mathrm{ns}}$ & -0.32 & $-0.51^{\star *}$ & -8.46 & $-1453.94^{*}$ & -5.55 & $182.25^{\mathrm{ns}}$ & 1.10 & $101.84^{\mathrm{ns}}$ & 0.64 & $186.53^{* *}$ & 12.91 \\
\hline $\mathrm{X}_{2}$ & $-8.24^{*}$ & -3.43 & $0.16^{\mathrm{ns}}$ & 0.22 & $-0.62^{\star *}$ & -11.47 & $43.94^{\mathrm{ns}}$ & 0.19 & $-113.98^{\mathrm{ns}}$ & -0.77 & $-125.60^{\mathrm{ns}}$ & -0.88 & $44.97^{\star}$ & 3.48 \\
\hline $\mathrm{R}^{2}$ & \multicolumn{2}{|c|}{0.934} & \multicolumn{2}{|c|}{0.915} & \multicolumn{4}{|c|}{0.836} & \multicolumn{2}{|c|}{0.932} & \multicolumn{2}{|c|}{0.928} & \multicolumn{2}{|c|}{0.933} \\
\hline
\end{tabular}

${ }^{*} \mathrm{p}<0.05 ;{ }^{* *} \mathrm{p}<0.01 ;$ and ${ }^{\text {nn}}$ no significant.

specific mechanical energies and water solubility index, but a positive linear effect on set back viscosity.

The SME may be defined as the energy input transmitted to the material being extruded by the screws, which characterizes the extruder operations and is often correlated to product quality, this can be also correlated to the degree of starch conversion of the system. In addition, any variable capable of affecting viscosity would correspondingly affect torque and SME, therefore water and sucrose contributed to decrease the viscosity of the system by reducing the total molecular weight of the mixture. SME is usually directly related to the expansion of expanded extrudates, in that case high expanded extrudates have high SME, since the energy spent during the extrusion process creates highly expanded extrudates which in turn is responsible for the puffed texture that is typical of expanded extrudates. In the particular case of non direct expanded extrudates, high SME values are not necessarily related with the volumetric expansion index. Although the water content and sugar affected SME, the water content has higher coefficient of regression than sugar on reducing SME, hence water has more effective energy dissipation as a plasticizer and overall molecular size reduction effect than sugar.

In the process of optimization, the roots for $\operatorname{SME}\left(\lambda_{1}, \lambda_{2}\right)$ of the auxiliary equation were $-1.39,-13.14$, respectively indicating that the optimum condition is at maximum. Figure 1 shows variation of SME with respect to water content and sucrose content. It was observed that with increase in water content and decrease in sucrose content, SME reached a maximum (32.0 and $0.0 \%$, respectively) and then decreased. High values of SME were also determined by some authors (BHATTACHARYA; HANNA, 1987; WIEDMANN, 1990) for extrusion of maize and wheat starches under low water content conditions. The effects of sucrose on SME were found similar when maize and wheat starches were compared (CARVALHO; MITCHELL, 2000). Also, a similar result was reported for the addition of sucrose and fructose to maize grits; up to $20 \%$ content, both sugars caused a decrease in SME (FAN; MITCHELL; BLANSHARD, 1996). As starch gelatinization is directly related to SME (ALVAREZ-MARTINEZ; KONDURY; HARPER, 1988), low starch conversions are expected under high water and sucrose content conditions.

Canonical results indicated that the nature of the optimum condition for WAI was a saddle point. The roots were 1.02 and -0.42 for $\lambda_{1}$ and $\lambda_{2}$, respectively, indicating that WAI was affected by water content. The maximum WAI values were found at low levels $(26 \%)$ of water content, independent of sucrose content (Figure 2a) demonstrating that low moisture content favored the increase of WAI. Moisture content affected WAI in the same lubricant effect responsible for cold viscosity increase 


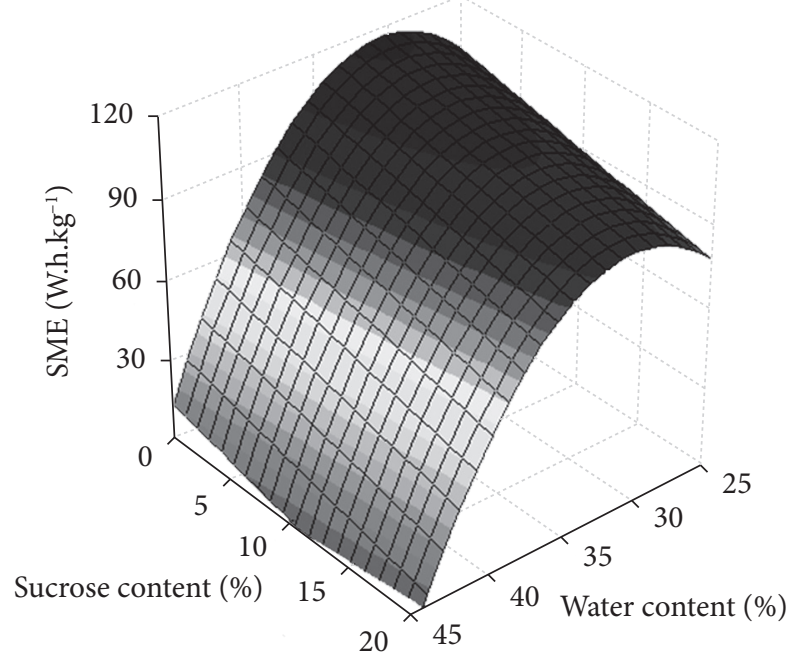

$90 \square 60 \square 30$

Figure 1. Effect of sucrose and moisture on specific mechanical energies (SME) of non-expanded cassava flour extrudate.

because only damaged starch granules absorb water at room temperature and swell, creating an increase in viscosity. After reaching a maximum, related to the degree of starch damage, WAI decreases with the onset of dextrinization (COLONNA; TAYEB; MERCIER, 1989).

WSI is related to the presence of soluble molecules, which is related to starch size reduction (COLONNA; TAYEB; MERCIER, 1989). The response surface plot of the model is shown in Figure $2 \mathrm{~b}$, and the canonical results indicated that the nature of the optimum condition was a saddle point. The roots were 0.07 and -0.53 for $\lambda_{1}$ and $\lambda_{2}$, respectively. The results indicated that WSI was the most affected by feeding water content and that WSI increased as the water content decreased. A similar trend has been reported by Ding et al. (2005), Anderson et al. (1969), Conway (1971), Gomez and Aguilera (1984) and Sefa-Dedeh and Saalia (1997). The effect of water content on decreasing WSI was alleviated by increasing the sucrose content. Maximum WSI, around 8.6, was found at intermediate levels (35\%) of water content on low levels ( $0 \%)$ of sucrose content (Table 2).

Figure 3 shows the response surfaces for the pasting properties of the non-expanded cassava flour extrudates. CV and PV were observed in the samples extruded at all water contents, independent of the sucrose content (Figure $3 a$ and $b$ ). The canonical results indicated that the nature of the optimum condition were a maximum and saddle point for CV and PV, respectively. Their roots $\left(\lambda_{1}, \lambda_{2}\right)$ were $-317.29,-1509.09$ and $183.91,-222.04$, respectively.

An increase of cold viscosity peak (CV) is related to the presence of damaged starch, which is a result of shearing forces during the extrusion, therefore greater water absorption and
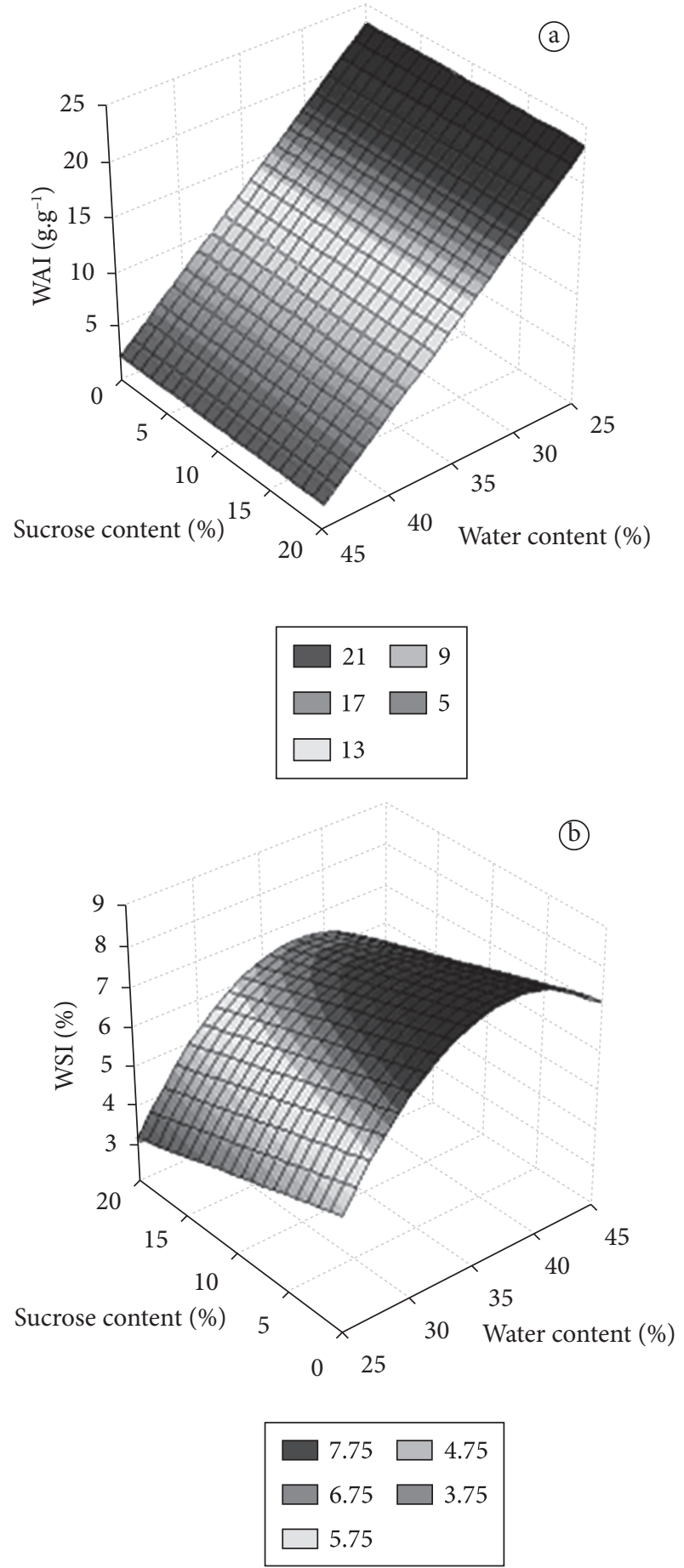

Figure 2. Effect of sucrose and moisture on: a) Water absorption index (WAI); and b) Water solubility index (WSI), of non-expanded cassava flour extrudate.

increase of paste viscosity at low temperatures is observed in the RVA analysis (WHALEN; BASON; BOOTH, 1996). On the other hand, the high peak viscosity (PV) value indicates the presence of non completed gelatinized starch granules. The maximum CV and PV were found at lower levels (28\%) and higher levels $(42 \%)$ of water content when the sucrose 

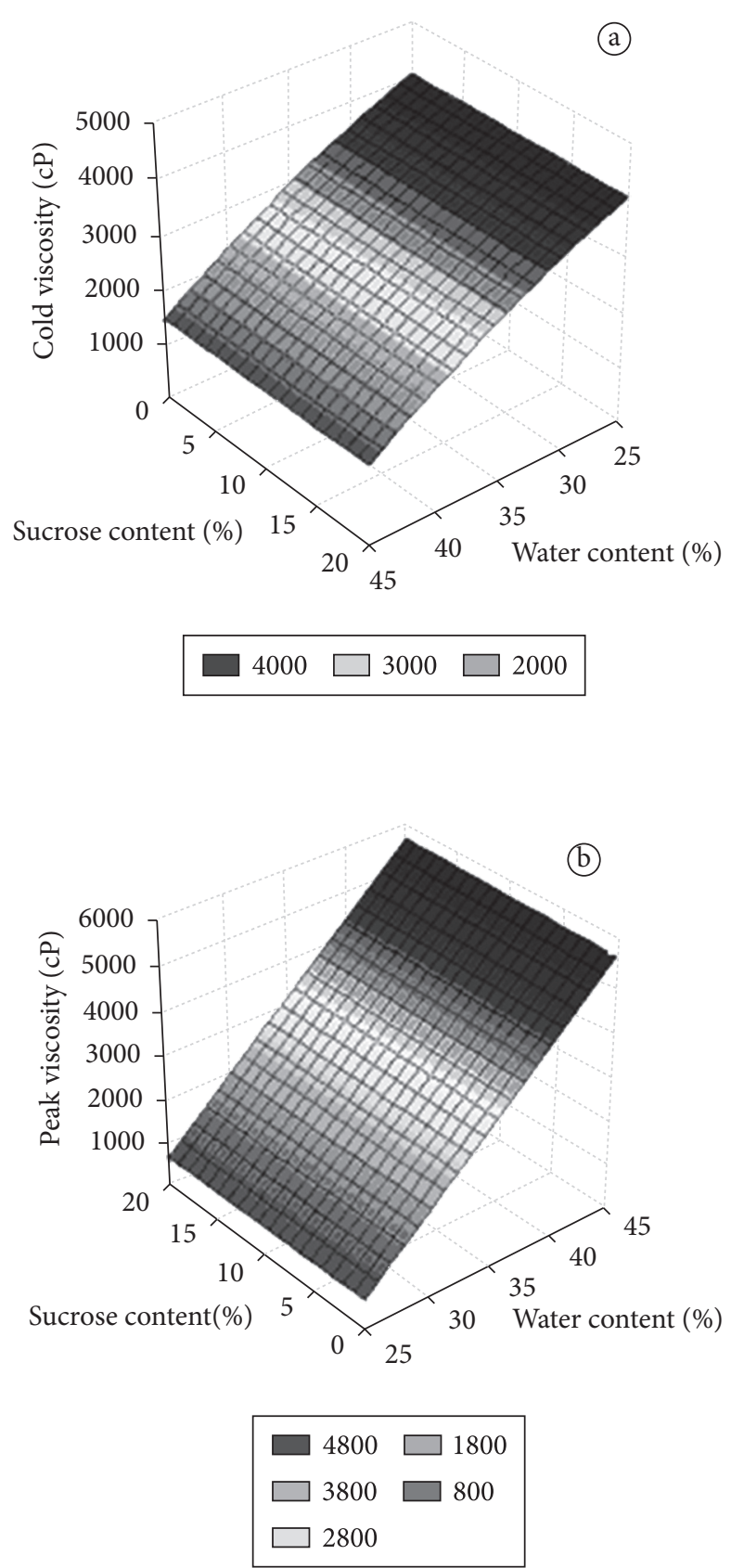
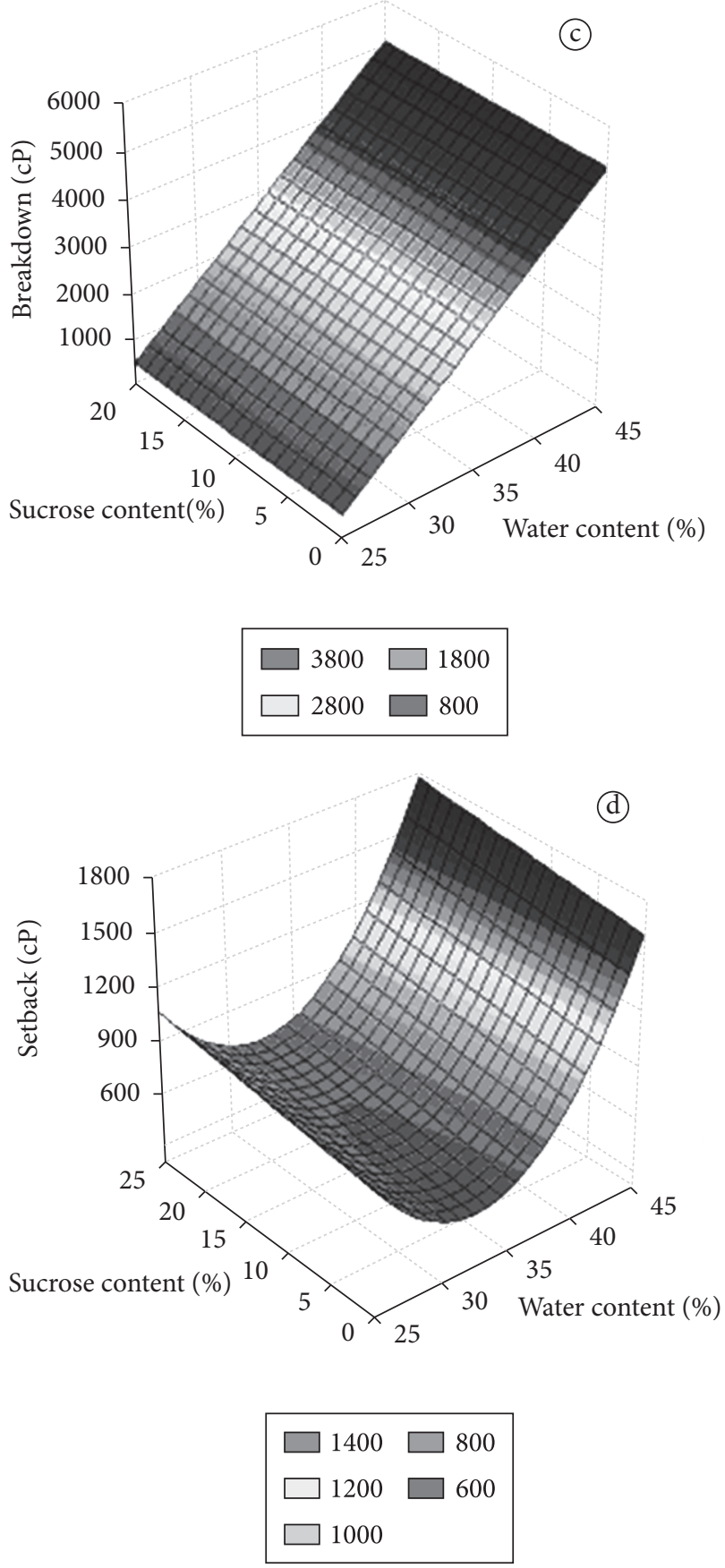

Figure 3. Effect of sucrose and moisture on: a) Cold viscosity; b) Peak viscosity; c) Breakdown; and d) Set back of non-expanded cassava flour extrudate.

content was kept low. CV and PV seemed to have a direct and inverse relationship to SME inputs, respectively. The nonexpanded cassava flour extrudates showed higher SME and CV, particularly at lower water contents and low PV values when the water content was increased. Starch granule breakdown has been reported to be increased at high SME inputs (MEUSER; GIMMLER; VAN LENGERICH, 1992), hence high CV values are observed in low water content extrusion condition as a result of starch fragmentation.
For optimizing the process, the roots for breakdown $\left(\lambda_{1}, \lambda_{2}\right)$ of the auxiliary equation were 103.12, -233.68 , and the roots for SB were 187.23, 33.59, indicating that the optimum condition is at saddle point and minimum, respectively. For BD, a similar curve to PV was obtained (Figure 3c). BD increased with the increasing of water content, indicating low starch conversion in high water content conditions. High values of $\mathrm{BD}$ are associated with high peak viscosity, which in turn, are related to starch swelling of the granules during heating (RAGAEE; 
Table 4. Simultaneous optimization parameters and the overall desirability.

\begin{tabular}{|c|c|c|c|c|c|c|c|c|c|}
\hline $\begin{array}{c}\text { Independent storage } \\
\text { condition }\end{array}$ & $\begin{array}{c}\text { Actual levels of } \\
\text { variables }\end{array}$ & SME & WAI & WSI & $\mathrm{CV}$ & PV & $\mathrm{BD}$ & SB & Overall desirability \\
\hline Water content & 37.6 & 9.9 & 7.9 & 90.5 & 2623.9 & 3758.6 & 3385.3 & 728.8 & 0.4966 \\
\hline Sugar content & 2.1 & & & & & & & & \\
\hline
\end{tabular}

ABDEL-AAL, 2006). The maximum breakdown was found at the highest water content (42\%) and lowest sucrose content.

Ragaee and Abdel-Aal (2006) reported that during cooling a re-association between starch molecules, especially amylose molecules, will result in the formation of a gel structure, which increases the final paste viscosity. In the RVA paste profile, this part of the curve is usually described as a setback region and is related to the retrogradation or reordering of starch molecules. Therefore, low setback values indicate a low rate of starch retrogradation. In this work, low levels of setback were found at $35 \%$ of water content and low levels of sucrose content (Figure 3d).

In Figure $3 \mathrm{c}$ and $\mathrm{d}$ it was observed that sugar content did not affect the pasting properties, which was not expected. According to Pongsawatmanit, Thanasukarn and Ikeda (2002), RVA viscosity profiles were strongly affected by adding sucrose to cassava starch-water systems. The peak viscosity as well as the final viscosity increased with increasing sucrose content. These authors reported that the antiplasticizing effects of sucrose indicated that a cassava starch-water system containing a higher amount of sucrose would require a higher energy to gelatinize. Since it is known that reducing the water content can affect gelatinization of starch by increasing pasting temperature and may inhibit the hydration of starch granules (RATNAYAKE; JACKSON, 2007). In concentrated systems, the competition between sucrose and starch for water, which is necessary for swelling and gelatinization of starch granules, may be critical (KALICHEVSKY; JAROSZKIEWICZ; BLANSHARD, 1993). In the present work, however, antiplasticizing effects were not seen when sucrose content was increased (Figure 3 ) probably due to the limited water content in the extrusion process available for starch conversion. Another explanation is particularly related to cassava starch granular structure, which seems to be converted easier under similar thermal shearing conditions imposed during extrusion than cereals, as observed in the work of Carvalho and Mitchell (2000).

Overall desirability score of 0.4966 was obtained when SME, WAI, WSI, CV, PV, BD and SB values were 90.5 W.h. $\mathrm{Kg}^{-1}$, $9.9(\mathrm{~g} / \mathrm{g}), 7.9 \%, 2623.9 \mathrm{cP}, 3758.6 \mathrm{cP}, 3385.3 \mathrm{cP}$ and $728.8 \mathrm{cP}$, respectively (Table 4 ). These values were obtained when the independent variables, i.e., water content and sucrose content were 37.6 and $2.1 \%$, respectively.

\section{Conclusion}

The water absorption index, cold viscosity, peak viscosity and breakdown were strongly influenced by moisture content. The water absorption index and cold viscosity decreased and peak viscosity and breakdown increased with the addition of water content, which in turn presented a negative and positive quadratic effect on specific mechanical energy, water solubility index and set back viscosity, respectively. The sucrose content had a negative linear effect on specific mechanical energy and water solubility index, but a positive linear effect on set back viscosity. Non antiplasticizing effect of sucrose content was observed on pasting properties, suggesting that sucrose might have not reduced water availability for starch conversion. The nature of the optimum point was a saddle point for water absorption index, water solubility index, peak viscosity and breakdown, while it was maximum and minimum for specific mechanical energy and cold viscosity and set back, respectively. These results will be useful for the production of non-expanded cassava flour extrudates with desirable functional properties for specific end users.

\section{References}

ALVAREZ-MARTINEZ, L.; KONDURY, K. P.; HARPER, J. M. A general model for expansion of extruded products. Journal of Food Sciences, v. 53, n. 2, p. 609-615, 1988.

ANDERSON, R. A. et al. Gelatinization of corn grits by roll and extrusion cooking. Cereal Science Today, v. 14, n. 1, p. 4-12, 1969.

BARRETT, A. et al. Effect of sucrose on the structure, mechanical strength and thermal-properties of corn extrudates. Carbohydrate Polymers, v. 26, n. 4, p. 261-269, 1995.

BHATTACHARYA, M.; HANNA, M. A. Influence of process and product variables on extrusion energy and pressure requirements. Journal of Food Engineering, v. 6, n. 2, p. 153-163, 1987.

CAMIRE, M. E.; CAMIRE, A.; KRUMHAR, K. Chemical and nutritional changes in foods during extrusion. Critical Reviews of Food Science and Nutrition, v. 29, n. 1, p. 35-57, 1990.

CARVALHO, C. W. P.; MITCHELL, J. R. Effect of sucrose on starch conversion and glass transition of nonexpanded maize and wheat extrudates. Cereal Chemistry, v. 78, n. 3, p. 342-348, 2001.

CARVALHO, C. W. P.; MITCHELL, J. R. Effect of sugar on the extrusion of maize grits and wheat flour. International Journal of Food Science and Technology, v. 35, n. 6, p. 569-576, 2000.

COLONNA, P.; TAYEB, J.; MERCIER, C. Extrusion cooking of starch and starchy products. In: MERCIER, C.; LINKO, P.; HARPER, J. M. (eds). Extrusion cooking. St Paul: AACC, 1989. p. 247-319.

CONWAY, H. F. Extrusion cooking of cereals and soybeans. Food Product Development, v. 5, n. 2, p. 27-29, 1971.

DERRINGER, G. C.; SUICH, R. Simultaneous optimization of several responses variables. Journal of Quality Technology, v. 12, n. 4, p. 214-219, 1980.

DING, Q. B. et al. The effect of extrusion conditions on the physicochemical properties and sensory characteristics of ricebased expanded snacks. Journal of Food Engineering, v. 66, n. 3, p. 283-289, 2005. 
FAN, J. T.; MITCHELL, J. R.; BLANSHARD, J. M. V. The effect of sugars on the extrusion of maize grits: 1 . The role of the glass transition in determining product density and shape. International Journal of Food Science and Technology, v. 31, n. 1, p. 55-65, 1996.

FARHAT, I. A. et al. Effect of sugars on retrogradation of waxy maize starch-sugar extrudates. Cereal Chemistry, v. 77, n. 2, p. 202-208, 2000.

FARHAT, I. A.; MOUSIA, Z.; MITCHELL, J. R. Structure and thermomechanical properties of extruded amylopectin-sucrose systems. Carbohydrate Polymers, v. 52, n. 1, p. 29-37, 2003.

GOMEZ, M. H.; AGUILERA, J. M. A physicochemical model for extrusion of corn starch. Journal of Food Science, v. 49, n. 1, p. 40-43, 63, 1984.

HSIEH, F. et al. Twin-screw extrusion of rice flour with salt and sugar. Cereal Chemistry, v. 70, n. 5, p. 493-498, 1993.

HSIEH, F.; PENG, I. C.; HUFF, H. E. Effects of salt, sugar and screw speed on processing and product variables of corn meal extruded with a twin-screw extruder. Journal of Food Science, v. 55, n. 1, p. 24-227, 1990.

JANG, J. K. et al. Effect of sucrose on glass transition, gelatinization, and retrogradation of wheat Starch. Cereal Chemistry, v. 78, n. 2, p. 186-192, 2001.

KHURI, A. Z.; CORNELL, J. A. Response surface design and analysis. New York: Marcel Dekker, 1987. p. 405.

MEUSER, F.; GIMMLER, N.; Van LENGERICH, B. A system analytical approach to extrusion. In: KOKINI, J. L.; HO, C. T.; KARWE, M. V. (eds). Food extrusion science and technology. New York: Marcel Dekker, 1992. p. 619-630.
MONTGOMERY, D. C. Design and analysis of experiments. New York: John Wiley \& Sons, 1997. p. 672.

MYERS, R. H. Response surface methodology. Boston: Allyn \& Bacon, 1971. p. 61-106.

PONGSAWATMANITA, R.; THANASUKARNA, P.; IKEDA, S. Effect of sucrose on RVA viscosity parameters, water activity and freezable water fraction of cassava starch suspensions. Science Asia, v. 28, n. 2, p. 129-134, 2002.

RAGAEE, S.; ABDEL-AAL, E. M. Pasting properties of starch and protein in selected cereals and quality of their food products. Food Chemistry, v. 95, n. 1, p. 9-18, 2006.

RATNAYAKE, W. S.; JACKSON, D. S. A new insight into the gelatinization process of native starches. Carbohydrate Polymers, v. 67, n. 4, p. 511-529, 2007.

SEFA-DEDEH, S.; SAALIA, F. K. Extrusion of maize: cowpea blends in a modiüed oil expeller. Journal of Science of Food and Agriculture, v. 73, n. 2, p. 160-168, 1997.

SOPADE, P. A.; LE GRYS, G. A. Effect of added sucrose on extrusion cooking of maize starch. Food Control, v. 2, n. 2, p. 103-109, 1991.

WHALEN, P. J.; BASON, M. L.; BOOTH, R. I. Measuring degree of cook in extruded foods using the Rapid Visco Analyser. In: WILLIAMS, Y. A.; WRIGLEY, C. W. (eds). AUSTRALIAN CEREAL CHEMISTRY CONFERENCE, 45., 1996, Melbourne. Proceedings... Melbourne: Royal Australian Chemical Institute, 1996. p. 289-293.

WIEDMANN, W. Control of cooking extrusion. In: ZUETHEN, P. et al. (eds). Processing andquality of foods: High Temperature Short Time (HTST) Processing. New York: Elsevier, 1990. p. 237-248. (v. 1). 